\title{
UPGRADING COURT ORGANIZATION AND ADMINISTRATION: A SMALL BLUEPRINT FOR A BIG JOB
}

\author{
Robert C. FinLex*
}

"T USTICE . . . is the great interest of man on earth."1 Thus spoke

Daniel Webster, wisely and well, at the funeral of Mr. Justice Story. In a closely related sense, Lord Bryce, English statesman, scholar and historian, has maintained that the American court system and its operation constitutes the backbone of American democracy and the American way of life. ${ }^{2}$ These statements probably would be considered reasonably accurate by most people today. In any event, it is certainly safe to state that our courts and their opera. tion are indeed of the utmost importance to Americans of all walks of life. Nevertheless, there is a strange paradox. In most of our states the courts and their procedures have, like Topsy, "just growed." Too little time and effort have been devoted to analyzing and evaluating our courts and their day-to-day handling of an almost infinite variety of judicial business. Too little time and effort on a continuing, broad-scale basis have been devoted to remedying defects and inadequacies in court structure, organization and administration.

Shortly after the turn of the century Roscoe Pound sounded an alarm, noting and criticizing archaic court methods and procedures. ${ }^{8}$ In the 1920's a healthy movement evolved seeking the establishment of state judicial councils, to be manned by lawyers, judges and laymen. ${ }^{4}$ The objective of the judicial council movement was continuing surveillance of courts and their operation in order to achieve a more efficient and effective administration of justice. In this same

- Associate Judge, Supreme Court of Washington. A.B. 1930, LL.B. 1934, Duke University; LL.M. 1936, Georgetown University. This article is the substance of an address delivered on June 12, 1964, at the Citizens' Conference on New Mexico Courts.

1 Seldes, The Great Quotations 730 (1960).

? See generally Bryce, The AmErican Commonivealth chs. XXII, XXVIII, XXXIII (new rev. ed. 1922).

${ }^{3}$ Pound, The Causes of Popular Dissatisfaction with the Administration of Justice, 29 A.B.A. REP. 395 (1906).

'Paul, The Judicial Council Movement, 10 J. Am. Jud. Soc'y 78 (1926). 
context, Mr. Justice Cardozo wrote of the need for a National Ministry of Justice. ${ }^{5}$ Moreover, the American Judicature Society has, for some fifty years, attacked indifference, inertia and red tape in this area and urged a program of court reform.

Despite this half-century of crusading, however, only recently have a sufficient number of judges, lawyers and laymen become interested and active in improving our courts so that it can be said that a healthy, growing movement for modernization and reform is actually underway. Some constructive and encouraging things are now proceeding to fruition. In several states ambitious programs designed to revamp, reorganize and revitalize the courts and their procedures from top to bottom have been undertaken, and in practically every state, significant if not encompassing developments in the area of court reform are underway. ${ }^{6}$

Let us approach the subject of effective court organization and administration by hypothesizing a newly created state, faced with the challenging and vital problem of establishing a functional court system. (This has in fact been the case in Alaska, Hawaii and Puerto Rico.) We might even imagine an older state about to launch an over-all program of reform and refurbishing with respect to the structure, organization and administration of its courts. (This has taken place in New Jersey.) What kind of blueprint or prescription may be offered regarding the factors to be considered and the tangible things which must be included in planning and establishing an ideal court system?

The first ingredient would involve an important human element -an awareness by people, including lawyers, judges and laymen, of the importance of a court system and its effective administration. This awareness must include a willingness periodically to re-examine the system with a view toward correcting defects and inadequacies.

With regard to tangible factors, any blueprint for a new or remodeled court system must emphasize the necessity of appropriate constitutional langnage under which a court system may be structured. Such language should be sufficiently flexible to enable the legislature (by statute) and the highest state court (by rule) to implement or supplement court organization and administration from

' Cardozo, $A$ Ministry of Justice, 35 Harv. L. Rev. I13 (1921).

- See Winters, The National Movement to Improve the Administration of Justice, 48 J. AM. JUd. Soc'y 17 (1964). 
time to time as needs for change are demonstrated. For example, the legislature should have continuing constitutional authority to create additional courts whenever necessary, without going through the awkward and lengthy process of annending the state constitution.

Initially, in our hypothetical state, a three-tiered judiciary should be established. First, courts of limited jurisdiction should be provided relative to geographical considerations and population needs. The second tier should consist of courts of general jurisdiction authorized to hear and decide the infinite variety of disputes and controversies that arise between citizen and citizen, and between the citizen and some branch of his government. Again, the number and territorial jurisdiction of such courts should be dictated by population and geography. The top tier in our ideal judiciary should consist of a court functioning largely as a reviewing or appellate tribunal. This court should have the usual original jurisdiction and authority to issue such extraordinary writs as habeas corpus, mandamus, prohibition and certiorari. In addition, it should have the authority to function administratively, with the responsibility for supervising the entire state court system being vested explicitly in the court acting through the chief justice as the chief administrative official of the state's judicial department.

As to the strictly appellate function of the state's highest court, I will forego any detailed comment regarding whether appeal should be a matter of right, or upon application and discretionary with the court. There is much to be said for the view that at least one opportunity for an appeal to a multi-judge tribunal as a matter of right should be available to the litigants in every case. A certiorari procedure, however, if the remedy is reasonably available on a thorough-going basis, might provide an adequate safety valve for the ill-considered or unjust result reached in a lower trial court. This procedure would, of course, be considerably short of a full-scale, orthodox appeal involving appellate briefs, argument and review of the complete record of the proceedings of the trial court.

The judiciary in our model state should be unified and integrated, with the chief justice, or a majority of the highest appellate court, having the authority and clear-cut responsibility for efficient administration and effective use of judicial manpower Most citizens and taxpayers, I think, would agree that no community -not even their own-should have the luxury, or perhaps prestige, of a full- 
time judge and court establishment if there is not sufficient judicial business to keep the judge and his court reasonably busy. This is most certainly true if judges and other court personnel are to be provided with adequate compensation, retirement and tenure.

If the chief justice of the state's highest court is to be the chief administrative official of the judicial branch, he must have the assistance of trained, competent administrative personnel. Actually, the state constitution might well provide for the establishment of the office of a state court administrator. The administrator and his staff would perform a number of functions. ${ }^{7}$ Basically, records should be kept; statistics should be collected and analyzed with respect to caseloads, work on hand, and the expenditure of judicial time in all of the courts of the three-tiered judiciary. Any modern business executive recognizes the importance of a perpetual inventory of his merchandise, and the number and nature of the cases on hand and the judicial time and manpower available constitute the inventory of a judicial establishment. Such an inventory is vital for purposes of matching manpower with the day-to-day needs which arise in the handling of court business.

All judges should either be lawyers or persons who have had legal training. It does not follow, however, that all lawyers are trained adequately to become judges. Accordingly, the court administrator and his staff, under the supervision of the chief justice, should be charged with the responsibility of providing seminars and other training sessions for new judges. The court administrator should maintain close contact with lawyers and judges in order to ascertain the causes of unusual and improper delay and isolate and eliminate other defects in the administration of justice. The court administrator and his staff should cooperate with the bench, the bar and the law schools in evaluating rules of civil and criminal procedure and other aspects of trial practice, with a view toward more efficient and effective processing of court business. Assistance should also be given by the court administrator and his staff to the chief justice and local presiding or administrative judges in devising better methods of central docketing and calendar control for greater effciency and effectiveness in the processing of litigation in large metropolitan, multiple-judge trial courts.

${ }^{7}$ See generally Invernizzi, The Office and Work of the Court Administrator, $43 \mathrm{~J}$. AM. Jud. Soc'x 186 (1960). 
Unquestionably, the rule-inaking power respecting civil and cuiminal procedure should be vested in the state's higinest court, either by judicial decision or constitutional provision.* Furthermore, this rule-making power should be exercised to finmulate, implement, and keep up-to-date, simplified, modern rules of procedure. Such rules should reject and seek to eliminate the "sporting theory of justice," i.e., the notion that a lawsuit is a game for the nimble and the quick-witted, substituting an operating principle to the effect that a lawsuit is a quest for the truth and for just solutions to human conflicts and problems. Provision should also be made by rule of court for annual conferences and training and refresher programs for judges and other court personnel, and appropriations should be made available to cover reasonable conference expenses. ${ }^{\circ}$

Two additional components of the ideal judicial establishment merit discussion: (1) judicial councils, and (2) lay organizations.

The most effective court system imaginable at any one point in time may become inefficient and outmoded with the passage of time and changes in the habits and activities of an increasing population. There is thus a need for continuing surveillance and evaluation in this area. The administration of justice is not static, and it is too important and significant in terms of our way of life and our system of government to be left to chance.

The terms judicial council and judicial conference are used somewhat interchangeably in some states, while they do not mean the same thing at all in others. ${ }^{10}$ Thus, some tentative definition is pertinent at this point. Let us assume that the term judicial conference denotes an organization of judges. Its purpose would be to enable judges to exchange shop talk, information and ideas. Such an organization should also offer "how to do it" work programs for judges on a continuing basis relative to problems arising in connection with court operation and the administration of justice. The judicial council, on the other hand, may be defined as an organiza-

${ }^{3}$ American Judicature Society, The Rule-Making Power of State Supreme Courts (1964). See State ex. rel. Foster-Wyman Lumber Co. v. Superior Court, 148 Wash. 1, 267 Pac. 770 (1928).

- See Section of Judicial Administration, ABA, The Improvemint of the Ad. IIMISTRATION OF JUSTICE ch. IV (4th ed. 1961).

10 See Institute of Judicial administramon, State Judicial Coungils, Judiciat. inferences, Couri Administrators and Rfi.aied Organizalions (1961). 
tion basically similar to those conceived in the mid-1920's. ${ }^{11}$ It would be composed of lawyers, judges, law professors, legislators, other public officials and laymen. The membership of a judicial council might vary from fifteen, to twenty-five or thirty. Its membership should be selected from different groups, by different appointing authorities, and for overlapping terms. The latter requirement would insure continuity in thinking and programming. Diffusion in appointive authority would mean that no one individual or group could dominate the judicial council. And representative membership is simply democratic in principle and requires no further comment.

The chairman of the judicial council might well be the chief justice; alternatively, the chairman could be selected by the members of the council for a fixed or indefinite term. Council representatives from the state's highest court should be selected by that court, while representatives of the other tiers of the court system should be selected by their colleagues. Lawyer representatives should be appointed by the president of the state bar association. Legislative members could, in part, be chosen by formula, namely, the chairmen of the judiciary committees of both houses of the state legislature. Additional legislators could be appointed by the chairman of the council, or by the council itself. Representatives of law schools should be selected by the dean or the faculty of each law school. The governor should appoint the lay members of the council, and the state attorney general should be a member ex officio.

Considering the cross-sectional characteristics of a group such as that described above, which would be charged with the duty of constant surveillance and evaluation of the law, the courts and the administration of justice, it would seem to follow that recommendations emanating from such a group would be well reasoned and deserving of support by the public, the legislature, the bench and the bar.

Lastly, and most importantly, mention should be made of the role of laymen in improving the administration of justice. Fundamentally, the administration of justice in a dynamic democracy is not the private concern of the members of the legal profession. Our courts belong to the public in a very real sense, and their primary purpose

\footnotetext{
11 See text accompanying note 2 supra.
} 
is public service. The bar and the bench are, of course, vital components of our court system, but it should be remembered that the practice of law on either side of the bench is essentially a very special public privilege, as well as a great public trust and responsibility. Inherently, the law, our legal institutions, and, to some extent, the legal profession itself are somewhat conserving in nature in that they operate on the basis of rules, uniformity, regularity and precedent.12 In this, of course, there is value in terms of establishing predictable standards with respect to socially acceptable human relationships and conduct. Paradoxically, however, this conserving modus operandi may generate negative social values to the extent that it resists change even in the face of rational evaluation indicating the need for new and different approaches and solutions regarding socio-legal problems. Thus, it is most important for laymen to add a catalytic force in the area of court reform by taking a continuing and active interest, in an organized context, in the courts, their operation, and the administration of justice.

12 "Law is by nature conservative. It crystallizes loose institutional and group habits into permanent principles of action; it forges the ways of men into stable structures which are highly resistant to change... [T]rue to its conserving function, law responds to new forces only after the consequences of these new forces in ideas, methods, and objectives have become well articulated in other institutions and the sciences concerned with these institutions." GARLAN, LEGAL REALISM AND JUSTICE 8 (1941). (Emphasis added.) 